\title{
Age-Specific Incidence Rates of Acute Coronary Syndrome in Japan \\ - A Special Gift From a Collaboration of Cardiologists and Epidemiologists -
}

\author{
Masaki Ohsawa, MD, PhD; Kozo Tanno, MD, PhD; Tomonori Itoh, MD, PhD
}

$\mathbf{R}$ esearchers in the MONICA study attempted to answer the question of whether differences in the incidence rate of coronary artery disease (CAD) existed between countries by using the unified criteria of acute myocardial infarction (AMI) and by evaluating the age-adjusted incidence rates using the WHO standard population. ${ }^{1}$ They found very high incidence rates of firstever AMI in Finland (600 per 100,000 person-years in males) and very low rates in China $(<100$ per 100,000 person-years in males). Unfortunately, data for Japan were not included in the study and Professor Ueshima later added it (based on Isomura's report ${ }^{2}$ ) to the results of the MONICA project and low incidence rates of AMI in Japan were revealed. ${ }^{3}$ However, these data were obtained more than 20 years ago and the current age distributions are very different from that time.

Japan is the most rapidly aging country in the world and the proportion of elderly people is very high. There should be a relatively large number of elderly people with AMI in Japan now; however, most previous studies in Japan have only addressed age-adjusted incidence rates of AMI or provided age-specific incidence rates of AMI only in middleaged people (shown in the Supplementary Table). Thus, it

\section{Article p1722}

would be interesting to know the incidence rates of CAD in all age categories, but there have been very few studies that provided age-specific incidence rates of acute coronary syndrome (ACS) or AMI, probably due to difficulties in conducting appropriate studies on age-specific incidence rates of CAD. Nielsen et al described 4 methodological problems for the determination of the incidence rate of ACS: (1) selection biases of the patients included in the study, (2) lack of identification and control of the background population, (3) uncertainties and inconsistencies in the use of diagnostic criteria, and (4) missing data. ${ }^{4}$

Table 1 shows studies conducted in Western countries that provided comprehensive age-specific incidence rates of CAD (AMI, ACS with/without sudden cardiac death (SCD)). ${ }^{4}{ }^{6}$ Both the prospective study in Demark ${ }^{4}$ and the comprehensive registry study in $\mathrm{Canada}^{6}$ provided similar age-specific incidence rates of AMI in middle-aged people and these incidence rates are also similar to the incidence rates in Western European nations in the WHO MONICA project. ${ }^{1}$ On the other hand, Canadian researchers showed

\begin{tabular}{|c|c|c|c|c|c|}
\hline $\begin{array}{c}\text { Study name } \\
\text { (published year) } \\
\text { Reference }\end{array}$ & Study design & $\begin{array}{l}\text { Analytical } \\
\text { method }\end{array}$ & Subjects & Outcomes & $\begin{array}{c}\text { Age-specific } \\
\text { incidence rates } \\
(95 \% \mathrm{Cl})\end{array}$ \\
\hline \multirow{6}{*}{$\begin{array}{l}\text { Göteborg/Sweden } \\
(1997)^{5}\end{array}$} & \multirow{3}{*}{$\begin{array}{l}\text { The Myocardial } \\
\text { Infarction Register in } \\
\text { Göteborg ( } n=450,000 \\
\text { inhabitants) }\end{array}$} & \multirow{3}{*}{$\begin{array}{l}\text { Age-specific crude } \\
\text { incidence rates }\end{array}$} & Women $35-44$ years old & \multirow{3}{*}{$\begin{array}{l}\text { The MONICA } \\
\text { criteria: non-fatal } \\
\text { AMI + fatal AMI }\end{array}$} & 14 \\
\hline & & & Women $45-54$ years old & & 55 \\
\hline & & & Women $55-64$ years old & & 194 \\
\hline & \multirow{3}{*}{$\begin{array}{l}\text { Non-fatal AMI in } \\
\text { hospital records SCD } \\
\text { among all persons } \\
\text { living in Göteborg, } \\
\text { Sweden, aged } 35-64 \\
\text { years were included }\end{array}$} & \multirow{3}{*}{$\begin{array}{l}\text { Age-specific crude } \\
\text { incidence rates }\end{array}$} & Men 35-44 years old & \multirow{3}{*}{$\begin{array}{l}\text { The MONICA } \\
\text { criteria: non-fatal } \\
\text { AMI + fatal AMI }\end{array}$} & 62 \\
\hline & & & Men 45-54 years old & & 272 \\
\hline & & & Men 55-64 years old & & 687 \\
\hline
\end{tabular}

(Table 1 continued the next page.)

The opinions expressed in this article are not necessarily those of the editors or of the Japanese Circulation Society.

Received June 2, 2021; accepted June 3, 2021; J-STAGE Advance Publication released online July 13, 2021

Department of Internal Medicine (M.O., T.I.), Department of Hygiene and Preventive Medicine (K.T.), Iwate Medical University,

Morioka; Department of Internal Medicine, Morioka Tsunagi Onsen Hospital, Morioka (M.O.), Japan

Mailing address: Masaki Ohsawa, MD, PhD, Department of Internal Medicine, Morioka Tsunagi Onsen Hospital, 64-9 Oirino

Tsunagi, Morioka 020-0055, Japan. E-mail: m-ohsawa@k2.dion.ne.jp

All rights are reserved to the Japanese Circulation Society. For permissions, please e-mail: cj@j-circ.or.jp

ISSN-1346-9843 
Study name (published year)

Reference

Aarhus/Denmark $(2007)^{4}$

Canadian

Cardiovascular

Outcomes

Research (2009) ${ }^{6}$

\section{Study design}

Prospective cohort of residents of the municipality of Aarhus, Denmark, aged 30-69 years $(n=138,290)$

Observation period: April 2000 to March 2002

\section{(1) Annual Canadian} Mortality Database $(n=18,102,2,004$ death certificates)

(2) Canadian Institute for Health Information's Hospital Morbidity Database $(n=56,759$, 2,004 inhospital records) ( $n=180,102$ inhospital patients and death certificates) Observation period: 1994-2004

\section{Analytical method}

Age-specific crude incidence rates

Age-specific crude incidence rates
Subjects

Women 30-39 years old Women 40-49 years old Women 50-59 years old Women 60-69 years old Women age-adjusted 30-69 years old

Men 30-39 years old

Men 40-49 years old

Men 50-59 years old

Men 60-69 years old

Men age-adjusted

30-69 years old

Crude annual incidence Women 20-49 years old rate (per 100,000

person-years) $=$ total annual no. of cases of AMI as numerator/ annual population of Canada National Census as denominator Direct age-adjustment was performed using the 1991 Canadian population census as the standard
Women 50-64 years old Women 65-74 years old Women $\geq 75$ years old Women overall

Men 20-49 years old Men 50-64 years old Men 65-74 years old Men $\geq 75$ years old Men overall
Age-specific incidence rates (95\% Cl)

25

73

157

Definite AMI + unstable angina+ SCD

$$
\begin{array}{r}
39 \\
156 \\
472 \\
1,106 \\
331
\end{array}
$$

Death certificates

(D) + inhospital

1.4 (death); 15.7 (inhospital) records of patients with AMI $(\mathrm{H})$

$18.6(\mathrm{D}) ; 125.4(\mathrm{H})$

90.6 (D); $374.8(\mathrm{H})$

$524.5(\mathrm{D}) ; 1,009.6(\mathrm{H})$

$$
64.2 \text { (D) }
$$

Death certificates

$7.2(\mathrm{D}) ; 66.9(\mathrm{H})$

D) + inhospital

records of patients

$69.6(\mathrm{D}) ; 422.2(\mathrm{H})$

$212.2(\mathrm{D}) ; 764.3(\mathrm{H})$

\begin{tabular}{|c|c|c|c|c|c|}
\hline $\begin{array}{c}\text { Study name } \\
\text { (published year) } \\
\text { Reference }\end{array}$ & Study design & $\begin{array}{l}\text { Analytical } \\
\text { method }\end{array}$ & Subjects & Outcomes & $\begin{array}{c}\text { Age-specific } \\
\text { incidence rates } \\
(95 \% \mathrm{Cl})\end{array}$ \\
\hline \multirow{14}{*}{$\begin{array}{l}\text { Hiroshima/Nagasaki } \\
\text { study }(1990)^{7}\end{array}$} & \multirow{14}{*}{$\begin{array}{l}\text { Hiroshima and Nagasaki } \\
\text { Prefecture prospective } \\
\text { cohorts } \\
\text { Observation period: } \\
1958-1984 \text { ( } n=20,141) \\
360 \text { cases of AMI (definite } \\
\text { and possible) }\end{array}$} & \multirow{14}{*}{$\begin{array}{l}\text { Average age- } \\
\text { adjustment was } \\
\text { performed using the } \\
\text { age distribution of the } \\
\text { cohort study }\end{array}$} & Women $30-39$ years old & \multirow{7}{*}{$\begin{array}{l}\text { The MONICA } \\
\text { criteria: definite } \\
\text { and probable AMI } \\
\text { not including SCD }\end{array}$} & 0.3 \\
\hline & & & Women $40-49$ years old & & 8.7 \\
\hline & & & Women $50-59$ years old & & 30.9 \\
\hline & & & Women $60-69$ years old & & 132.2 \\
\hline & & & Women $70-79$ years old & & 345.7 \\
\hline & & & Women $\geq 80$ years old & & 557.2 \\
\hline & & & Women age-adjusted & & 78.8 \\
\hline & & & Men 30-39 years old & \multirow{7}{*}{$\begin{array}{l}\text { The MONICA } \\
\text { criteria: definite } \\
\text { and probable AMI } \\
\text { not including SCD }\end{array}$} & 5.1 \\
\hline & & & Men 40-49 years old & & 34.8 \\
\hline & & & Men $50-59$ years old & & 136.1 \\
\hline & & & Men $60-69$ years old & & 419.1 \\
\hline & & & Men $70-79$ years old & & 683.4 \\
\hline & & & Men $\geq 80$ years old & & 908.7 \\
\hline & & & Men age-adjusted & & 204.9 \\
\hline \multirow[t]{12}{*}{ JMS cohort $(2008)^{8}$} & \multirow{12}{*}{$\begin{array}{l}12 \text { areas and area-related } \\
\text { rural hospital-based } \\
\text { prospective cohorts } 10.7 \\
\text { years follow-up period } \\
(1992-)(n=12,490) \\
\text { inhospital records ( } n=92 \\
\text { consecutive patients with } \\
1 \text { st-ever AMI) not including } \\
\text { SCD }\end{array}$} & \multirow{12}{*}{$\begin{array}{l}\text { Direct age-adjustment } \\
\text { was performed using } \\
\text { the } 1985 \text { Japan } \\
\text { population census as } \\
\text { the standard }\end{array}$} & Women $\leq 39$ years old & \multirow{6}{*}{$\begin{array}{l}\text { The MONICA } \\
\text { criteria } \\
\text { Inhospital records } \\
\text { of patients with } \\
\text { AMI not including } \\
\text { SCD }\end{array}$} & 0.0 \\
\hline & & & Women $40-49$ years old & & 0.0 \\
\hline & & & Women $50-59$ years old & & 25.5 \\
\hline & & & Women $60-69$ years old & & 45.8 \\
\hline & & & Women $\geq 70$ years old & & 217.1 \\
\hline & & & Women age-adjusted & & 34.2 \\
\hline & & & Men $\leq 39$ years old & \multirow{6}{*}{$\begin{array}{l}\text { The MONICA } \\
\text { criteria } \\
\text { Inhospital records } \\
\text { of patients with } \\
\text { AMI not including } \\
\text { SCD }\end{array}$} & 19.1 \\
\hline & & & Men $40-49$ years old & & 16.8 \\
\hline & & & Men 50-59 years old & & 80.2 \\
\hline & & & Men 60-69 years old & & 202.1 \\
\hline & & & Men $\geq 70$ years old & & 424.3 \\
\hline & & & Men age-adjusted & & 123.7 \\
\hline
\end{tabular}

743.9 (D); 1,509.4 (H) 86.7 (D)

ACS, acute coronary syndrome; AMI, acute myocardial infarction; SCD, sudden cardiac death. 


\begin{tabular}{|c|c|}
\hline $\begin{array}{c}\text { Study name } \\
\text { (published year) } \\
\text { Reference }\end{array}$ & Study design \\
\hline Yamagata (2016) ${ }^{9}$ & $\begin{array}{l}\text { Multicenter-hospital-based } \\
\text { Inhospital records ( } n=5,325 \\
\text { consecutive patients with } \\
1 \text { st-ever AMI not including } \\
\text { cardiac death) } \\
\text { Study period: } 1994-2010\end{array}$ \\
\hline Takashima (2008) ${ }^{10}$ & $\begin{array}{l}\text { Population-based, data from } \\
\text { all hospitals ( } 3 \text { hospitals } \\
\text { inside the area and a Shiga } \\
\text { University Hospital), county } \\
\text { ambulance records and } \\
\text { county death certificates } \\
\text { (cross-checked by } \\
\text { epidemiologists and } \\
\text { cardiologists) were } \\
\text { certificated by } \\
\text { epidemiologists in Shiga } \\
\text { University of Medical } \\
\text { Science (total } \\
\text { population=55,451; } \\
\text { census 2000) } \\
\text { Observation period: } \\
\text { 1990-2001 }\end{array}$ \\
\hline
\end{tabular}

Iwate (2017) $)^{11}$

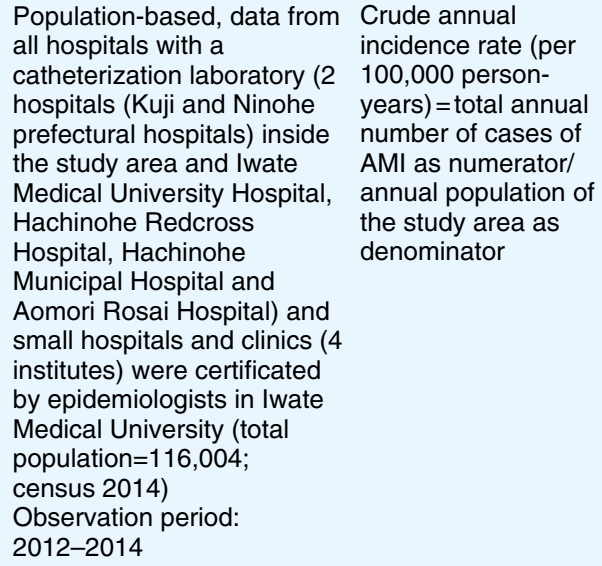
ncidence rate (per 100,000 personyears) $=$ total annual number of cases of AMI as numerator/ annual population of the study area as denominator

\section{Analytical method}

Crude annual incidence rate (per 100,000 personyears) $=$ total annual no. of cases of AMI as numerator/annual population of each area as denominator Direct age-adjustment was performed using the 2005 Japan population census as the standard

Crude annual incidence rate (per 100,000 personyears) $=$ total annual number of cases of AMI as numerator/ annual population of the study area as denominator
Subjects

Women $\leq 64$ years old

Women 65-74 years old

Women $\geq 75$ years old

Women age-adjusted

Men $\leq 64$ years old

Men 65-74 years old

Men $\geq 75$ years old

Men age-adjusted

Women 45-54 years old

Women 55-64 years old

Women 65-74 years old

Women 75-84 years old

Women $\geq 85$ years old

Men $\leq 35$ years old

Men 35-44 years old

Men 45-54 years old

Men 55-64 years old

Men 65-74 years old

Men 75-84 years old

Men $\geq 85$ years old

Women 30-39 years old

Women 40-49 years old

Women 50-59 years old

Women 60-69 years old

Women $70-79$ years old

Women $80-89$ years old

Men 30-39 years old

Men 40-49 years old

Men 50-59 years old

Men 60-69 years old

Men 70-79 years old

Men 80-89 years old
Outcomes

The MONICA criteria

Inhospital records of patients with AMI not including SCD

The MONICA criteria

Inhospital records of patients with AMI not including

SCD

Age-specific incidence rates $(95 \% \mathrm{Cl})$

4.0

(3.5-4.6)

44.1

(39.3-49.1)

101.1

(92.2-110.0)

20.3

(18.4-22.3)

23.4

(21.5-25.3)

131.1

(122.0-140.1)

178.1

(162.8-193.4)

45.6

(43.1-48.1)

The MONICA

criteria: definite

AMI including

SCD

27.2

(7.4-71.9)

78.7

(34.9-154.1)

92.2

(34.7-201.2)

121.5

(22.9-381.2)

2.9

The MONICA

criteria: definite

AMI including

SCD

(0.2-12.6)

33.9

(11.2-80.2)

88.2

(41.5-166.1)

84.1

(41.4-153.2)

135.4

(66.7-246.8)

283.8

(145.5-503.0)

428.6

(115.9-1,131.2)

The MONICA

criteria: definite

AMI including

SCD

$$
5.7
$$

(1.9-12.3)

$$
4.7
$$

(1.3-10.9)

11.8

(5.8-20.3)

24.4

(15.3-35.7)

67.5

(52.3-85.6)

204.5

(177.4-234.5)

11.2

(5.4-19.6)

56.4

criteria: definite

AMI including

SCD

(42.3-72.7)

78.3

(61.6-97.3)

146.4

(123.2-171.6)

239.5

(210.1-271.8)

420.2

(380.7-462.1)

ACS, acute coronary syndrome; AMI, acute myocardial infarction; SCD, sudden cardiac death. 
very high incidence rates of inhospital AMI in elderly people, both female $(1,009.6$ per 100,000 person-years) and male $\left(1,509.4\right.$ per 100,000 person-years) ${ }^{6}$

Table 2 shows studies that provided age-specific incidence rates of CAD in Japan, including 2 prospective cohort studies, ${ }^{7,8}$ a multihospital-based registry study, ${ }^{9}$ and 2 population-based registry studies. ${ }^{10,11}$ The incidence rates in middle-aged individuals in the 2 prospective cohort studies $^{\mathbf{1 0 , 1 1}}$ were higher than the rates in the report by Isomura. ${ }^{2}$ Age-specific incidence rates in elderly people in the JMS cohort, ${ }^{\mathbf{8}}$ Takashima AMI registry $\mathbf{1 0}^{\mathbf{0}}$ and Northern Iwate Registry ${ }^{11}$ were similar, but the rates in the Yamagata AMI registry9 were lower than in those studies. Collecting patients' data from tertiary referral hospitals would definitely contribute to a selection bias. Very old patients and patients with very serious conditions such as malnutrition are not likely to be transported to the tertiary referral hospitals because of their very low chance of recovery. Moreover, cases of SCD attributable to ACS were not included in the Yamagata registry. ${ }^{9}$ These might be reasons for the underestimation of incidence rates, especially in elderly people. Although prospective studies can provide reliable data for the incidence rates of $\mathrm{CAD}$, the study design requires a large-scale sample and an observation period of 10 years or longer.

In an inventory survey of $\mathrm{CAD}$, the most formidable challenge is how to handle SCD. Because it has been shown that CAD accounts for more than $75 \%$ of the total number of SCDs, ${ }^{12}$ much effort was made in previous studies to recruit patients with AMI who died out of hospital. Researchers in the Takashima AMI registry ${ }^{10}$ and Northern Iwate Heart Disease registry ${ }^{11}$ consisted of not only cardiologists but also epidemiologists and the collaboration of these 2 teams almost completed inventory surveys including SCD, whereas tertiary referral hospital-based registries such as the Yamagata AMI registry ${ }^{9}$ and the Miyagi AMI registry ${ }^{13}$ showed relatively low incidence rates probably due to underestimation. Researchers in the Yamagata AMI registry recently published a study that addressed out-of-hospital cardiac arrest (OHCA) ${ }^{14}$ Surprisingly, they showed that more than $50 \%$ of the total cases of AMI were attributed to OHCA. If they re-estimated the agespecific incidence rates of AMI using data that included cases of OHCA, the results would be different from the previously published data.

In this issue of the Journal, Ogata et $\mathrm{a} \mathbf{1}^{15}$ report on their attempt to reveal accurate age-specific incidence rates of AMI and ACS including SCD by bringing together cardiologists and epidemiologists. They show not only comprehensive age-specific incidence rates of AMI, but also age-specific incidence rates of ACS, including fatal/nonfatal AMI, unstable angina and SCD. They utilized data from the Nobeoka Medical Control Consultative Committee for Emergency Transportation and found cases of highly suspected CAD-related SCD among cases of OHCA. This achievement should be warmly praised.

However, all the studies (Takashima, Iwate and Nobeoka) were conducted in rural areas and there have been no studies on age-specific incidence rates of CAD in urban areas of Japan. We hope that a further collaboration of cardiologists and epidemiologist will conduct a com- plete inventory survey in an urban area of Japan. That team would certainly give us a special gift.

\section{Conflicts of Interest}

None declared.

\section{References}

1. Tunstall-Pedoe H, Kuulasmaa K, Amouyel P, Arveiler D, Rajakangas AM, Pajak A. Myocardial infarction and coronary deaths in the World Health Organization MONICA Project: Registration procedures, event rates, and case-fatality rates in 38 populations from 21 countries in four continents. Circulation 1994; 90: 583-612.

2. Isomura K. Study on the development of the community-based long-term follow-up system for cardio-cerebrovascular diseases in 1993 Annual Report of the Cardiovascular Diseases. National Cardiovascular Center: Suita 1994 (in Japanese).

3. Ueshima H. Explanation for the Japanese paradox: Prevention of increase in coronary heart disease and reduction in stroke. $J$ Atheroscler Thromb 2007; 14: 278-286.

4. Nielsen KM, Foldspang A, Larsen ML, Gerdes LU, Rasmussen $\mathrm{S}$, Faergeman O. Estimating the incidence of the acute coronary syndrome: Data from a Danish cohort of 138290 persons. Eur J Cardiovasc Prev Rehabil 2007; 14: 608-614.

5. Wilhelmsen L, Rosengren A, Johansson S, Lappas G. Coronary heart disease attack rate, incidence and mortality 1975-1994 in Goteborg, Sweden. Eur Heart J 1997; 18: 572-581.

6. Tu JV, Nardi L, Fang J, Liu J, Khalid L, Johansen H. National trends in rates of death and hospital admissions related to acute myocardial infarction, heart failure and stroke, 1994-2004. CMAJ 2009; 180: E118-E125.

7. Kodama K, Sasaki H, Shimizu Y. Trend of coronary heart disease and its relationship to risk factors in a Japanese population: A 26-year follow-up, Hiroshima/Nagasaki study. Jpn Circ J 1990; 54: $414-421$.

8. Ishikawa S, Kayaba K, Gotoh T, Nago N, Nakamura Y, Tsutsumi A, et al. Incidence of total stroke, stroke subtypes, and myocardial infarction in the Japanese population: The JMS Cohort Study. $J$ Epidemiol 2008; 18: 144-150.

9. Wanezaki M, Watanabe T, Nishiyama S, Hirayama A, Arimoto $\mathrm{T}$, Takahashi $\mathrm{H}$, et al. Trends in the incidences of acute myocardial infarction in coastal and inland areas in Japan: The Yamagata AMI Registry. J Cardiol 2016; 68: 117-124.

10. Rumana N, Kita Y, Turin TC, Murakami Y, Sugihara H, Morita $\mathrm{Y}$, et al. Trend of increase in the incidence of acute myocardial infarction in a Japanese population: Takashima AMI Registry, 1990-2001. Am J Epidemiol 2008; 167: 1358-1364.

11. Nakamura M, Tanaka F, Segawa T, Takahashi T, Matsuura Y, Sakai T, et al. Temporal trends in the incidence and clinical features of acute myocardial infarction in a Japanese rural area from 2006 to 2014. Circ J 2017; 81: 1854-1861.

12. Hayashi M, Shimizu W, Albert CM. The spectrum of epidemiology underlying sudden cardiac death. Circ Res 2015; 116: 1887-1906.

13. Cui Y, Hao K, Takahashi J, Miyata S, Shindo T, Nishimiya K, et al. Age-specific trends in the incidence and in-hospital mortality of acute myocardial infarction over 30 years in Japan: Report from the Miyagi AMI Registry Study. Circ J 2017; 81: 520-528.

14. Toshima T, Hirayama A, Watanabe T, Goto J, Kobayashi Y, Otaki Y, et al. Unmet needs for emergency care and prevention of prehospital death in acute myocardial infarction. $J$ Cardiol 2021; 77: 605-612.

15. Ogata S, Marume K, Nakai M, Kaichi R, Ishii M, Ikebe S, et al. Incidence rate of acute coronary syndrome including acute myocardial infarction, unstable angina, and sudden cardiac death in Nobeoka City for the super-aged society of Japan. Circ J 2021; 85: $1722-1730$.

\section{Supplementary Files}

Please find supplementary file(s);

http://dx.doi.org/10.1253/circj.CJ-21-0502 